\title{
Economics of foodgrain Crops in Himachal Pradesh: A Study of Solan District
}

\author{
Sushma Kumari* \\ Lecturer in Econimics, Department of Higher Education Himachal Pradesh \\ *Corresponding author: sushmakum21@gmail.com
}

\begin{abstract}
Main purpose of the study is to determine the cost structure, profit margin and returns to scale of foodgrain crops. Foodgrain crops selected for investigation are wheat, maize and paddy. Solan district was selected purposively. Data have been collected by personal interviews. Per hectare cost of cultivation of wheat, maize and paddy worked out as size-wise of holding and compared the cost of these crops and found that medium farms had maximum cultivation cost because their farm size were large, gross returns and net returns also worked out. Further Cobb- Douglous production function has been to get the estimates of elasticities of the inputs land, human labour, bullock labour, manure\& fertilizers, seeds and capital. Results show that inputs have significant impact on the production of foodgrain crops and also show constant, increasing and decreasing returns to scale.
\end{abstract}

Keywords: retuns to scale,gross returns, net returns

Cite This Article: Sushma Kumari, and Sikander Kumar, "Economics of Foodgrain Crops in Himachal Pradesh: A Study of Solan District.” American Journal of Rural Development, vol. 6, no. 1 (2018): 21-28. doi: 10.12691/ajrd-6-1-4.

\section{Introduction}

Johnston and Mellor (1961) [1], Johnston and Kilby (1975) [2] agriculture play a very important role in transition process of countries, agriculture generates market for industrial product, provide food and agriculture raw material for industrial processing, build adequate food supplies that are crucial factors in sustaining price stability, provide exports to earn foreign exchange, supplies the non-agricultural sector with capital and labour, in the market oriented economy, eases the process of industrialization through gradual accumulation of entrepreneurship and marketing capabilities in the agriculture sector. The level of contribution by agriculture to economic development depends upon the quantum of income generated from farming activities and surplus generated if any.

Since we know that agriculture sector facing hardships of low agricultural productivity in most of developing countries, low agricultural growth is unable to keep pace with the fast and persistently growing population pressure in these countries. and many other problems such as small size of holdings, fragmented land holdings due to heavy pressure of population, nuclear families, scattered farms can't be looked after properly and waste time of agriculturists, poor quality of livestock, lack of desire to produce more agriculture production, weak will power towards diversification of agriculture, poverty, traditional inputs, scarcity of land deficiency of electricity, land ownership, literacy, low income, low savings, low capital formation, backwardness, slow progress of land reforms, finance problems, traditional methods of agriculture, irrigation problem, lack of markets in rural areas, low prices and low net returns to scale of agriculture product makes farmer inactive to produce agriculture production.

Returns to scale is an important aspect in agriculture sector because it is helpful to know input output relationship. It has defined by Varian (1992 [3] 2005 [4]) returns to scale and farm size productivity relationship is most important aspect of the study of agriculture. Returns to scale refers to the change in output when all the inputs are changed proportionately. For a given proportional increase of all the inputs, output is increased by the same, larger and smaller proportions there are constant, increasing and decreasing returns to scale respectively. It is very significant to measure the importance of returns to scale in agriculture. It is helpful to know the cost of output, profit margin of crops, and also helpful in changing of agriculture sectors structure and to make agriculture more profitable profession and also provide information to the government of a country about the problems of agriculture and then government can take initiatives for the solution of problems by formulating policies for the development of agriculture.

\section{Review}

Measuring the cost structure, profitability returns to scale and of agricultural production has many fold importance to farmers and government agencies to understand the structure of agriculture sector and it is important for further policy making. Many experts had conducted studies on the issues of agricultural production costs, returns to scale etc. some of studies had given in this article to support. Studies conducted by (Chaudhary et al. 1969 [5], Gupta et al. 1976 [6], Carter 1984 [7] Sharma et al. 1989 [8], Thakur et al. 1992 [9], Randev et al. 1992 
[10], Paul and Michael 1993 [11], Ahmad and Qureshi 1999 [12], Tripathi and Singh 2005 [13], Gajja et al. 2007 [14], Kamat et al 2007 [15], Dogra et al.2007 [16] Maity and Chatterjee 2010 [17], Bala et al. 2011 [18], shows increasing, decreasing and constant returns to scale and give various reasons of increasing returns such as intensive use of inputs, use of modern inputs, off season vegetable crops, scientific management of crops, efficient use of labour and other factor of production, credit facilities to farmers etc. and reasons of decreasing returns to scale are modern inputs has no impact in the production of foodgrain, allocative input inefficiency increase the cost of production and suggestions to get increasing returns to scale they suggested technological change and agricultural research, improve quality of agriculture inputs, to formulate a proper policy to increase agriculture production.

\section{Research Design, Area and Questions}

In the present study out of the twelve districts of Himachal Pradesh Solan district was selected. Solan district have five blocks out of which two blocks i.e. Kunihar \& Nalagarh are selected randomly and purposively. After selecting these two blocks, a list of panchayats was prepared made with the help of Block Development Officer (BDO) of these blocks. After that three largest Panchayats i.e. (area wise and population wise) selected from each block. Thus the number of panchayat became six. After selecting panchayats, a lists of villages was prepared with the help of Patwari (village level revenue official) falling under these panchayats. In next stage the largest three villages were selected from each panchayat so nine villages selected from each block and a total number of 18 villages were selected for the study. In the last stage, a list of all farmers of these villages was prepared along with information about operational holdings with the help of village "Patwari" and after that these farmers are classified according to their operational holding into three categories i.e.

i. Marginal farmers having land less than one hectare.

ii. Small farmers having land between 1 to 2 hectares.

iii. Medium farmers having land 2 hectares and above.

In order to achieve the objectives of the study both primary as well as secondary data have been used. Secondary data collected from the related books, journals, reports, economic surveys, census, Directorate of Land Records, Statistical abstract etc. However, the study is based on primary data. So for this purpose first of all, a preliminary field visit has been made to get information regarding the farming system, traditions, custom, communication network, historical background and institutional arrangements etc. The data pertaining to age and sex wise family composition, literacy, operated area i.e.( owned land, leased-in and leased-out land), quality of agricultural inputs i.e. seeds, fertilizers, manures, implements, insecticides, pesticides, family human labour days(hired-in or hired-out, permanent attached labour), bullock labour days ( own bullock labour days or hired bullock labour days), tractorization, mechanization as well as the quantity and value of output of foodgrain.

Questions of the research were to find out cost of cultivation of wheat, maize paddy, gross returns, net returns and returns to scale on these crops. For studying the cost structure Cost A, Cost B, Cost C calculated and for returns to scale on selected farms, the Cobb-Douglas type of production function is used in its following general form and the contribution of specific resource to output

$$
\mathrm{Y}=\mathrm{aX}_{1}{ }^{\mathrm{b} 1} \mathrm{X}_{2}{ }^{\mathrm{b} 2} \mathrm{X}_{3}{ }^{\mathrm{b} 3} \ldots \ldots, \ldots \mathrm{X}_{\mathrm{n}}{ }^{\mathrm{bn}}
$$

Where,

$\mathrm{Y}$ is the dependent variable;

$\mathrm{X}_{1}$ to $\mathrm{Xn}$ are explanatory variables; $\mathrm{a}$ is constant intercept; $\mathrm{b}_{1}$ to bn are production elasticities for $\mathrm{X}_{1}$ to $\mathrm{Xn}$.

This type of function can be transformed into the logarithmic form so that it can be solved by the methods of least squares.

$$
\begin{aligned}
\log \mathrm{y}= & \log \mathrm{a}+\mathrm{b} 1 \operatorname{og} \mathrm{X} 1+\mathrm{b}_{2} \log \mathrm{X}_{2} \\
& +\ldots \ldots \ldots \ldots \mathrm{b}_{\mathrm{n}} \log \mathrm{Xn} .
\end{aligned}
$$

This function has been selected mainly because in this type of production function the regression coefficients are direct measure of elasticities. [2] Moreover, the trial with various forms of functions, the Cobb-Douglas production function is observed to be giving best results in the goodness of fit. The statistical significance levels of regression coefficients have been worked out in order to find out the goodness of fit. [5] This has been carried out by calculating the ' $\mathrm{t}$ ' statistics by following formula for regression coefficients.

$$
t=\frac{b i}{\sqrt{\operatorname{var}(b i)}} \text { with }(\mathbf{n}-\mathbf{k}-\mathbf{I}) \text { degree of freedom. }
$$

The denominator in the above expression represents the standard error of the corresponding coefficient.

\subsection{Returns to Scale}

The sum of the production coefficients of all the independent variables in the regression equation provides us directly with the ready estimate of the returns to scale and also the degree of homogeneity of the production function. Returns to scale are termed to' be increasing if sum of elasticity coefficients is greater than one, constant if equal to one and decreasing if less than one. The difference of the sum of elasticity coefficients (bi's) from unity is gauged statistically by t-test as follows:

$$
t=\frac{\sum b i-1}{\sqrt{\sum_{i=1}^{6} \operatorname{var} b i+2 \sum_{i \neq j} \text { Cov.bibj }}}
$$

Where

$\mathrm{i}=$ is not equal to $\mathrm{j}$.

$\mathrm{i}=1,2,3, \ldots \ldots .6$.

$\mathrm{j}=1,2,3, \ldots \ldots 6$.

\subsection{Hypothesis}

1. The null hypothesis, H0, is that the sum of elasticity coefficient is not significant deviate from unity and hence, indicates constant returns to scale.

2. Alternative hypothesis, $\mathrm{H} 1$, is that their sum is significantly deviate from unity and greater than 
unity, therefore, indicating increasing returns to scale.

3. Alternative hypothesis, $\mathrm{H} 2$, is that their sum is significantly deviate from unity and it is less than one , implies, decreasing returns to scale

\subsection{Cost Calculation}

In order to calculate returns to scale it is essential to study the input structure and cost of cultivation on farms in different size classes and have an idea about the share of various input factors in total costs. For determining the cost structure of various farms, cost A1, A2, B and C have been estimated. it has been noticed that farmer buy some of the factor inputs like fertilizers, seeds, tractor, threshers etc. from the market to cultivate crops. The imputed values of some inputs are counted for the calculation of total cost. Therefore, we have imputed the value of all owned factors on the basis of prevailing market price to reach cost $\mathrm{C}$. However, the imputation of various factor inputs such as family labour on the prevailing market wage rate is not based on sound economic reasoning.

The various cost concepts which have been used in our analysis are:

Cost A1: The items included in the cost A1 are:

1. Value of hired in labour

2. Value of Bullock labour (owned + hired -in)

3. Value of seeds (purchased + home grown)

4. Value of farm yard manures (own+ purchased)

5. Value of chemical fertilizers

6. Insecticide and pesticides

7. Irrigation charges

8. Tractor/ machinery (owned+ hired-in)
9. Depreciation charges

10. Miscellaneous charges

11. Interest on working capital

12. Land revenue

Cost A2: Cost A1 + rent paid for leased- in land

Cost B: Cost A2 + rental value of own land and interest on fixed capital

Cost C: Cost B + imputed value of family labour

\section{Results and Discussion}

\subsection{Total Costs of All Foodgrain Crops}

Table 1 shows the break-up of costs into various costs on different farm size groups. As evident from the table that overall cost of cultivation of foodgrain crops are estimated to Rs. 34242.82.It can be further seen that the per hectare cost of cultivation wheat is less than its counterparts viz., maize and paddy.

The per hectare cost of these crops worked out Rs. 25717.05 for wheat, Rs. 27005.45 for maize, Rs. 63266.64 for paddy. Howerver, in respect of Cost A1 which comprises of all cash and kind expenses, per hectare cost of paddy cultivation is more than wheat and maize, the Cost A1 for paddy cultivation is Rs.34960.12 Rs. 12650.53 for maize, and Rs. 10080.95 for wheat. Cost of cultivation of these crops in different farm size groups, it can be seen that there is increasing tendency in all the costs with the increase in farm size. It is also significant to note that per hectare cost of paddy cultivation is more on all the farm size as compared to its counterpart's viz.wheat and maize.

Table 1. Break-up of Total Cost into Various Cost Concepts- A Comparative Analysis of All Foodgrain crops (Wheat + Maize+ Paddy)

(Rs. per Hectare)

\begin{tabular}{|c|c|c|c|c|c|c|}
\hline Sr. No. & Crop & Return/ Cost & Marginal Farmers & Small Farmers & Medium Farmers & Overall Farmers \\
\hline \multirow[t]{4}{*}{1} & Wheat & Gross Return & 21835.45 & 49504 & 132175 & 50820 \\
\hline & & Cost A1 & 7964.14 & 10675.3 & 41068.56 & 10080.95 \\
\hline & & Cost B & 10624.67 & 17150.5 & 57823.56 & 16514.05 \\
\hline & & Cost C & 17619.21 & 18290.5 & 72693.56 & 25717.05 \\
\hline \multirow[t]{5}{*}{2} & Maize & Gross Return & 9679.24 & 19143.75 & 47810.34 & 18204.37 \\
\hline & & Cost A1 & 6340.39 & 16621.16 & 29024.33 & 12650.53 \\
\hline & & Cost A2 & 6387.55 & 16704.49 & 29024.33 & 12699.71 \\
\hline & & Cost B & 7757.92 & 20150.36 & 35834.67 & 15976.49 \\
\hline & & Cost C & 15870.18 & 30408 & 48455.33 & 27005.45 \\
\hline \multirow[t]{4}{*}{3} & Paddy & Gross Return & 17516.66 & 68047.61 & 170032.00 & 93673.43 \\
\hline & & Cost A1 & 6321.94 & 23449 & 65231.39 & 34960.12 \\
\hline & & Cost B & 10030.49 & 35697.57 & 90677.79 & 51977.58 \\
\hline & & Cost $\mathrm{C}$ & 17274.93 & 44968.99 & 107413.79 & 63266.64 \\
\hline \multirow[t]{5}{*}{4} & All Foodgrain Crops & Gross Return & 15996.58 & 40530.25 & 116215.95 & 43603.13 \\
\hline & & Cost A1 & 7095.62 & 16255.56 & 36426.07 & 17250.01 \\
\hline & & Cost A2 & 7202.45 & 16289.17 & 36479.26 & 17326.07 \\
\hline & & Cost B & 9273.7 & 22561.28 & 52424.57 & 23926.49 \\
\hline & & Cost C & 15990.36 & 33128.5 & 67096.91 & 34242.82 \\
\hline
\end{tabular}

Source: Field Survey

Note: Gross Return or Gross Revenue i.e. gross value of output (main + by product). 
Per hectare cost of cultivation of all crops estimated Rs. 15990.36 for marginal farmers, Rs. 33128.5 for small farmers and Rs. 67096.91 for medium farmers. The substantive point that has emerged from a close examination of the per hectare cost of cultivation of paddy between different farm size is that all the cost concept viz., cost $A 1$,cost $A 2$, cost $B$ and cost $C$ are high on medium farms as compared to marginal and small farmers. The main explanation of this point is that medium farms have more land in comparison to marginal and small farmers.

\subsection{Gross Returns}

Gross output per hectare is a general index of farm level efficiency in resource use. This is the per hectare cost, it provides a rough indication of profitability of farm business. Gross returns of wheat, maize, paddy and total foodgrain crops presented in Table 1 it provides information of gross returns per hectare on various crops. The gross revenue had increasing tendency with the increase in the size of holdings. By taking, the gross revenue for the wheat it is Rs.50820, Rs. 18204.37 for maize, Rs. 93673.43 for paddy and on all foodgrain it is Rs. 43603.13.

Farm Business Income (FBI), Returns to Family Labour Management (RFLM) and Net Returns from All Foodgrain Crops (Wheat+ Maize+ Paddy).

FBI, RFLM and NR presented in Table 2 on per hectare cultivation of land in case of all foodgrain crops gives FBI, RFLM, and NR in the tone of about Rs. 26277.06, 19676.64and 9360.31 respectively. FBI, RFLM and NR are high on paddy crop as compared to wheat and maize crop. In maize crop NR are negative on all category of farmers, FBI per hectare increases as farm size expands. However, in respect of net returns it is positive in case of marginal, small and medium farmers. On wheat crop, NR is found positive on all farm size categories and further in the case of paddy crop NR is positive on all farms. The negative returns on maize crop may be attributed to the low value crops, and there may be some other reasons like low productivity, lack of irrigation facilities, crops destroyed by wild animal etc.

\subsection{Production Function Analysis of Wheat Crop}

On marginal farmers it is observed from the Table 3 that the elasticity coefficient for seeds $\left(\mathrm{X}_{5}\right)$, capital $\left(\mathrm{X}_{6}\right)$ were positive and significant at 5 percent and 1 percent. The elasticity coefficient for land $\left(\mathrm{X}_{1}\right)$, bullock labour $\left(\mathrm{X}_{3}\right)$ and manure and fertilizers $\left(\mathrm{X}_{4}\right)$ were positive and non-significant. The elasticity coefficient for human labour $\left(\mathrm{X}_{2}\right)$ was found to be negative and non-significant. In the case of small farmers it is observed that, the elasticity coefficient for capital $\left(\mathrm{X}_{6}\right)$ was positive and significant at 1 percent level. The elasticity coefficient for human labour $\left(\mathrm{X}_{2}\right)$, bullock labour $\left(\mathrm{X}_{3}\right)$, seeds $\left(\mathrm{X}_{5}\right)$ were positive and non-significant and elasticity coefficient for manure and fertilizers $\left(\mathrm{X}_{4}\right)$ was negative and non-significant. Further on medium farmers it is observed that elasticity coefficient for land $\left(\mathrm{X}_{1}\right)$, manure and fertilizers $\left(\mathrm{X}_{4}\right)$, capital $\left(\mathrm{X}_{6}\right)$ were positive and non-significant. The elasticity coefficient for human labour $\left(\mathrm{X}_{2}\right)$, bullock labour $\left(\mathrm{X}_{3}\right)$, seeds $\left(\mathrm{X}_{5}\right)$ were negative and non-significant. On overall farmers it is observed that elasticity coefficient for manure and fertilizers $\left(\mathrm{X}_{4}\right)$, seeds $\left(\mathrm{X}_{5}\right)$ and capital $\left(\mathrm{X}_{6}\right)$ were positive and significant at 5 percent, 1 percent and 1 percent level. For land $\left(\mathrm{X}_{1}\right)$ it was positive and nonsignificant and for human labour $\left(\mathrm{X}_{2}\right)$ and bullock labour $\left(\mathrm{X}_{3}\right)$ it was negative and non- significant.

Table 2.

(Rs. per Hectare)

\begin{tabular}{|c|c|c|c|c|c|}
\hline Sr. No. & Crops/ Returns & Marginal Farmers & Small Farmers & Medium Farmers & Overall Farmers \\
\hline \multirow[t]{4}{*}{1} & Wheat & & & & \\
\hline & FBI & 13780.41 & 38828.7 & 90981.44 & 40664.05 \\
\hline & RFLM & 11210.78 & 32353.5 & 74351.44 & 34305.95 \\
\hline & NR & 4216.24 & 31213.5 & 59481.44 & 25102.95 \\
\hline \multirow[t]{4}{*}{2} & Maize & & & & \\
\hline & FBI & 3291.69 & 2439.26 & 18786.01 & 5504.66 \\
\hline & RFLM & 1921.32 & -1006.61 & 11975.667 & 2227.88 \\
\hline & NR & -6190.94 & -11264.25 & -644.99 & -8801.08 \\
\hline \multirow[t]{4}{*}{3} & Paddy & & & & \\
\hline & FBI & 10639.17 & 44598.61 & 104800.60 & 58557.06 \\
\hline & RFLM & 7486.17 & 32350.04 & 79354.21 & 41695.85 \\
\hline & NR & 241.73 & 23078.62 & 62618.21 & 30406.79 \\
\hline \multirow[t]{4}{*}{4} & All Foodgrain & & & & \\
\hline & FBI & 8794.13 & 24241.08 & 79736.69 & 26277.06 \\
\hline & RFLM & 6722.88 & 17968.97 & 63791.38 & 19676.64 \\
\hline & NR & 6.22 & 7401.75 & 49119.04 & 9360.31 \\
\hline
\end{tabular}

Source: Field Survey. 
Table 3. Regression Coefficients for Wheat Crop

\begin{tabular}{|c|c|c|c|c|c|}
\hline S.N. & Items & Marginal Farmers & Small Farmers & Medium Farmers & Overall Farmers \\
\hline 1 & Constant (Log a) & $\begin{array}{l}6.262^{*} \\
(2.858)\end{array}$ & $\begin{array}{c}3.087 \\
(5.246)\end{array}$ & $\begin{array}{c}9.269 \\
(89.164)\end{array}$ & $\begin{array}{l}3.988 * * \\
(2.233)\end{array}$ \\
\hline 2 & Land in Hect $\left(\mathrm{X}_{1}\right)$ & $\begin{array}{l}1.583 \\
(.398) \\
\end{array}$ & $\begin{array}{c}(-) .443 \\
(.743)\end{array}$ & $\begin{array}{c}1.747 \\
(12.680) \\
\end{array}$ & $\begin{array}{c}.121 \\
(.283)\end{array}$ \\
\hline 3 & Human Labour in Days $\left(\mathrm{X}_{2}\right)$ & $\begin{array}{c}(-) .192 \\
(.199)\end{array}$ & $\begin{array}{c}.634 \\
(.509)\end{array}$ & $\begin{array}{c}(-) .115 \\
(.150) \\
\end{array}$ & $\begin{array}{c}(-) .101 \\
(.126)\end{array}$ \\
\hline 4 & Bullock Labour Days $\left(\mathrm{X}_{3}\right)$ & $\begin{array}{c}.017 \\
(.068)\end{array}$ & $\begin{array}{l}.009 \\
(.044)\end{array}$ & $\begin{array}{l}(-) .009 \\
(.031)\end{array}$ & $\begin{array}{c}(-) .003 \\
(.026)\end{array}$ \\
\hline 5 & Manure \& Fertilizer in Rs. $\left(\mathrm{X}_{4}\right)$ & $\begin{array}{c}.110 \\
(.148) \\
\end{array}$ & $\begin{array}{c}(-) .298 \\
(.540) \\
\end{array}$ & $\begin{array}{c}.262 \\
(.265) \\
\end{array}$ & $\begin{array}{l}.225^{* *} \\
(.119) \\
\end{array}$ \\
\hline 6 & Seeds in Rs. $\left(\mathrm{X}_{5}\right)$ & $\begin{array}{l}.571^{* *} \\
(.303) \\
\end{array}$ & $\begin{array}{c}.294 \\
(. .617) \\
\end{array}$ & $\begin{array}{c}(-) .718 \\
(.12 .581)\end{array}$ & $\begin{array}{l}.660^{*} \\
(.251) \\
\end{array}$ \\
\hline 7 & Capital or Tractorization in Rs $\left(\mathrm{X}_{6}\right)$ & $\begin{array}{l}.078^{*} \\
(.029) \\
\end{array}$ & $\begin{array}{l}.617^{*} \\
(.164)\end{array}$ & $\begin{array}{c}.506 \\
(.215) \\
\end{array}$ & $\begin{array}{l}.066^{*} \\
(.015) \\
\end{array}$ \\
\hline 8 & $\mathrm{R}^{2}$ & .641 & .293 & .696 & .789 \\
\hline 9 & $\mathrm{~N}$ & 110 & 50 & 40 & 200 \\
\hline 10 & $\left(\sum \mathrm{bi}\right)$ & $2.167^{*}$ & 0.813 & $1.673^{*}$ & $0.968^{*}$ \\
\hline 11 & “t” Value for Deviation From Unity & 5.53 & 1.722 & 3.497 & 10.92 \\
\hline
\end{tabular}

Note: Figures in Parentheses are Standard Error.

* Significant at1 Percent Level.

** Significant at 5 Percent Level

*** Significant at 10 Percent Level

$\mathrm{R}^{2}$ Denotes Coefficient of Multiple Determinants

N Denotes Number of Observation.

Table 4. Regression Coefficients for Maize Crop

\begin{tabular}{|c|c|c|c|c|c|}
\hline Sr.No. & Items & Marginal Farmers & Small Farmers & Medium Farmers & Overall Farmers \\
\hline \multirow{2}{*}{1} & \multirow{2}{*}{ Constant(Log a) } & 2.888 & $7.948 *$ & $7.145^{*}$ & $9.309 *$ \\
\hline & & $(-2.892)$ & $(-2.877)$ & $(-4.063)$ & $(-1.822)$ \\
\hline \multirow{2}{*}{2} & \multirow{2}{*}{ Land in $\operatorname{Hect}\left(\mathrm{X}_{1}\right)$} & (-).694* & $(-) .211$ & 0.409 & $.488 *$ \\
\hline & & $(-0.288)$ & $(-0.234)$ & $(-0.477)$ & $(-0.179)$ \\
\hline \multirow{2}{*}{3} & \multirow{2}{*}{ Human Labour in Days $\left(\mathrm{X}_{2}\right)$} & $(-) .112$ & 0.047 & 0.527 & $(-) .823^{*}$ \\
\hline & & $(-0.232)$ & $(-0.369)$ & $(-0.426)$ & $(-0.157)$ \\
\hline \multirow{2}{*}{4} & \multirow{2}{*}{ Bullock Labour Days $\left(\mathrm{X}_{3}\right)$} & 0.062 & 0.193 & 0.015 & 0.049 \\
\hline & & $(-0.132)$ & $(-0.21)$ & $(-0.098)$ & $(-0.081)$ \\
\hline \multirow{2}{*}{5} & \multirow{2}{*}{ Manure \& Fertilizer in Rs. $\left(\mathrm{X}_{4}\right)$} & $.486 * *$ & 0.141 & 0.297 & $.490 *$ \\
\hline & & $(-0.281)$ & $(-0.262)$ & $(-0.365)$ & $(-0.173)$ \\
\hline \multirow{2}{*}{6} & \multirow{2}{*}{ Seeds in Rs. $\left(\mathrm{X}_{5}\right)$} & $.323^{*}$ & 0.055 & $(-) .293$ & 0.011 \\
\hline & & $(-0.118)$ & $(-0.067)$ & $(-0.245)$ & $(-0.05)$ \\
\hline \multirow{2}{*}{7} & \multirow{2}{*}{ Capital or Tractorization in Rs $\left(\mathrm{X}_{6}\right)$} & 0.005 & $(-) .014$ & 0.007 & 0.012 \\
\hline & & $(-0.022)$ & $(-0.031)$ & $(-0.043)$ & $(-0.01)$ \\
\hline 8 & $\mathrm{R}^{2}$ & 0.122 & 0.039 & 0.54 & 0.475 \\
\hline 9 & $\mathrm{~N}$ & 106 & 48 & 30 & 184 \\
\hline 10 & Sum of Elasticity Coefficients ( $\sum$ bi) & 0.07 & 0.211 & 0.955 & $0.227 *$ \\
\hline 11 & "t” Value for Deviation From Unity & 1.511 & 0.514 & 2.076 & 5.123 \\
\hline
\end{tabular}

Note: Figures in Parentheses are Standard Error.

*Significant at 1 Percent Level.

**Significant at 5 Percent Level

***Significant at 10 Percent Level

$\mathrm{R}^{2}$ Denotes Coefficient of Multiple Determinants

N Denotes Number of Observation.

\subsection{Production Function Analysis of Maize Crop}

Maize is the major crop for the kharif season in the state. On marginal farmers it is observed that the elasticity coefficient for manure and fertilizers $\left(\mathrm{X}_{4}\right)$, seeds $\left(\mathrm{X}_{5}\right)$ were positive and significant at 5 percent and 1 percent level. In In Table 4 the elasticity coefficient for bullock labour $\left(\mathrm{X}_{3}\right)$ and capital $\left(\mathrm{X}_{6}\right)$ were positive and non-significant. Negative and signicant at 1 percent level elasticity coefficient for land $\left(\mathrm{X}_{1}\right)$.

Elasticity coefficient for human labour $\left(\mathrm{X}_{2}\right)$ was negative and non-significant. On small farmers elasticity coefficient 
for human labour $\left(\mathrm{X}_{2}\right)$, bullock labour $\left(\mathrm{X}_{3}\right)$, manure and fertilizers $\left(\mathrm{X}_{4}\right)$ and seeds $\left(\mathrm{X}_{6}\right)$ were positive and non- significant. The elasticity coefficient for land $\left(\mathrm{X}_{1}\right)$ and capital $\left(\mathrm{X}_{6}\right)$ were negative and non-significant. In the case of medium farmers the elasticity coefficient for land $\left(\mathrm{X}_{1}\right)$, human labour $\left(\mathrm{X}_{2}\right)$, bullock labour $\left(\mathrm{X}_{3}\right)$, manure and fertilizers $\left(\mathrm{X}_{4}\right)$ and capital $\left(\mathrm{X}_{6}\right)$ were positive and non- signicant, negative and non-significant in the case of seeds $\left(\mathrm{X}_{5}\right)$. For overall farms elasticity coefficient for land $\left(\mathrm{X}_{1}\right)$ and manure and fertilizers $\left(\mathrm{X}_{4}\right)$ were positive and significant at 1 percent level. The elasticity coefficient for bullock labour $\left(\mathrm{X}_{3}\right)$, seeds $\left(\mathrm{X}_{5}\right)$ and capital $\left(\mathrm{X}_{6}\right)$ were positive and non- significant. Elasticity coefficient for human labour $\left(\mathrm{X}_{2}\right)$ was negative and significant at 1 percent level.

\subsection{Production Function Analysis of Paddy Crop}

Paddy is another major crop of kharif season. Table 5 shows on marginal farmers elasticity coefficient for land $\left(\mathrm{X}_{1}\right)$ was positive and significant at 5 percent level and for human labour $\left(\mathrm{X}_{2}\right)$, bullock labour $\left(\mathrm{X}_{3}\right)$, seeds $\left(\mathrm{X}_{5}\right)$, capital $\left(\mathrm{X}_{6}\right)$ were positive and non-significant. In the case of manure and fertilizers $\left(\mathrm{X}_{4}\right)$ it was negative and nonsignificant. On small farmers the elasticity coefficient for seeds $\left(\mathrm{X}_{5}\right)$ was positive and significant at 1 percent level and for human labour $\left(\mathrm{X}_{2}\right)$, capital $\left(\mathrm{X}_{6}\right)$ were positive and non- significant. The elasticity coefficient for land $\left(\mathrm{X}_{1}\right)$ and manure and fertilizers were negative and significant at 1 percent level and negative and non-significant in the case of bullock labour $\left(\mathrm{X}_{3}\right)$. Further in the case of medium farmers it is observed that the elasticity coefficient for land $\left(\mathrm{X}_{1}\right)$ and manure and fertilizers $\left(\mathrm{X}_{4}\right)$, capital $\left(\mathrm{X}_{6}\right)$ were positive and non-sigificant, negative and non-significant in the case of human labour $\left(\mathrm{X}_{2}\right)$, bullock labour $\left(\mathrm{X}_{3}\right)$, and seeds $\left(X_{5}\right)$. On overall farmers it is observed that the elasticity coefficient for $\operatorname{land}\left(\mathrm{X}_{1}\right)$ was positive and significant at 1 percent level and for seeds $\left(\mathrm{X}_{5}\right)$ and capital $\left(\mathrm{X}_{6}\right)$ elasticities were positive and non-significant. Negative and non-significant in the case of human labour $\left(\mathrm{X}_{2}\right)$, bullock labour $\left(\mathrm{X}_{3}\right)$ and manure and fertilizers $\left(\mathrm{X}_{5}\right)$.

\subsection{Production Elasticities for All Foodgrain Crops (Wheat+Maize+ Paddy)}

The results of Cobb- Douglas production function for pooled data analysis have been presented in the Table 6 . On marginal farmers elasticity coefficient of seeds $\left(\mathrm{X}_{5}\right)$ positively significant at 5 percent level, manure and fertilizer $\left(\mathrm{X}_{4}\right)$ positively significant at 1 percent level. Coefficient of human labour $\left(\mathrm{X}_{2}\right)$ and bullock labour $\left(\mathrm{X}_{3}\right)$ negatively significant at 1 percent level and coefficient of other inputs like land $\left(\mathrm{X}_{1}\right)$, capital $\left(\mathrm{X}_{6}\right)$ were positive and non-significant. In the case of small farmers the coefficient of land $\left(\mathrm{X}_{1}\right)$ found positive and significant at 1 percent probability level..Elasticities for bullock labour $\left(\mathrm{X}_{3}\right)$, seeds $\left(\mathrm{X}_{5}\right)$ and capital $\left(\mathrm{X}_{6}\right)$ were positive and non-significant. Negative and significant at one percent elasticities the case of human labour $\left(\mathrm{X}_{2}\right)$. Negative and non- significant elasticity in the case of manure and fertilizers $\left(\mathrm{X}_{4}\right)$ Further in the case of medium famers the coefficient of seed $\left(\mathrm{X}_{5}\right)$ is positive and significant at 5 per cent level and in the case of land $\left(\mathrm{X}_{1}\right)$ elasticity is positive and significant at 10 percent level. Positive and non-significant elasticities observed for human labour $\left(\mathrm{X}_{2}\right)$, manure and fertilizers $\left(\mathrm{X}_{4}\right)$, and capital or Tractorization $\left(\mathrm{X}_{6}\right)$. Negative and non-significant elasticity in the case of bullock labour $\left(\mathrm{X}_{3}\right)$.

Table 5. Regression Coefficients for Paddy Crop

\begin{tabular}{|c|c|c|c|c|c|}
\hline Sr.No. & Items & Marginal Farmers & Small Farmers & Medium Farmers & Overall Farmers \\
\hline \multirow{2}{*}{1} & \multirow{2}{*}{ Constant(Log a) } & 7.923* & $66.098^{*}$ & 23.878 & \multirow{2}{*}{$\begin{array}{c}8.762 * \\
()\end{array}$} \\
\hline & & $(-3.658)$ & $(-25.561)$ & $(-15.384)$ & \\
\hline 2 & Land in Hect. $\left(\mathrm{X}_{1}\right)$ & $(-0.387)$ & $(-3.391)$ & $(-1.915)$ & $(-0.232)$ \\
\hline \multirow{2}{*}{3} & \multirow{2}{*}{ Human Labour in Days $\left(\mathrm{X}_{2}\right)$} & 0.234 & 0.209 & $(-) .044$ & $(-) .014$ \\
\hline & & $(-1.157)$ & $(-0.582)$ & $(-0.507)$ & $(-0.237)$ \\
\hline \multirow{2}{*}{4} & \multirow{2}{*}{ Bullock Labour Days $\left(\mathrm{X}_{3}\right)$} & 0.112 & $(-) .185$ & $(-) .102$ & $(-) .071$ \\
\hline & & $(-0.342)$ & $(-0.614)$ & $(-0.085)$ & $(-0.088)$ \\
\hline \multirow{2}{*}{5} & \multirow{2}{*}{ Manure \& Fertilizer in Rs. $\left(\mathrm{X}_{4}\right)$} & $(-) .238$ & $(-) .421^{*}$ & 0.173 & $(-) .054$ \\
\hline & & $(-0.538)$ & $(-0.249)$ & $(-0.232)$ & $(-0.131)$ \\
\hline \multirow{2}{*}{6} & \multirow{2}{*}{ Seeds in Rs. $\left(X_{5}\right)$} & 0.263 & $9.897^{*}$ & $(-) 1.827$ & 0.239 \\
\hline & & $(-0.274)$ & $(-3.471)$ & $(-1.815)$ & $(-0.22)$ \\
\hline 7 & Capital or Tractorization in Rs $\left(\mathrm{X}_{6}\right)$ & $(-0.383)$ & $(-0.665)$ & $(-0.116)$ & $(-0.114)$ \\
\hline 8 & $\mathrm{R}^{2}$ & 0.81 & 0.782 & 0.847 & 0.879 \\
\hline 9 & $\mathrm{~N}$ & 18 & 21 & 25 & 64 \\
\hline 10 & Sum of Elasticity Coefficients ( $\sum$ bi) & $1.183^{*}$ & $1.249 *$ & $0.939 *$ & $1.098^{*}$ \\
\hline 11 & “t” Value for Deviation From Unity & 2.80 & 2.89 & 4.069 & 8.79 \\
\hline
\end{tabular}

Note: Figures in Parentheses are Standard Error.

* Significant at 1 Percent Level.

** Significant at 5 Percent Level

***Significant at 10 Percent Level

$\mathrm{R}^{2}$ Denotes Coefficient of Multiple Determinants

$\mathrm{N}$ Denotes Number of Observation. 
Table 6. Regression Coefficients for All Foodgrain Crops(Wheat+ Maize+Paddy)

\begin{tabular}{|c|c|c|c|c|c|}
\hline Sr.No. & Items & Marginal Farmers & Small Farmers & MediumFarmers & Overall Farmers \\
\hline 1 & Constant(Log a) & $\begin{array}{l}5.280^{*} \\
(1.547)\end{array}$ & $\begin{array}{l}13.829 * \\
(1.853)\end{array}$ & $\begin{array}{l}5.605^{*} \\
(1.647)\end{array}$ & $\begin{array}{l}8.837 \\
(.943)\end{array}$ \\
\hline 2 & Land in Hect.( $\left.\mathrm{X}_{1}\right)$ & $\begin{array}{c}.096 \\
(.169)\end{array}$ & $\begin{array}{l}1.108^{*} \\
(.285)\end{array}$ & $\begin{array}{l}.341^{* *} \\
(.190)\end{array}$ & $\begin{array}{l}.713^{*} \\
(.102)\end{array}$ \\
\hline 3 & Human Labour $\left(\mathrm{X}_{2}\right)$ & $\begin{array}{c}(-) .426^{*} \\
(.112) \\
\end{array}$ & $\begin{array}{c}(-) .804 * \\
(.307)\end{array}$ & $\begin{array}{c}.010 \\
(.180) \\
\end{array}$ & $\begin{array}{c}(-) .575^{*} \\
(.089) \\
\end{array}$ \\
\hline 4 & Bullock Labour Days $\left(\mathrm{X}_{3}\right)$ & $\begin{array}{l}(-) .128^{*} \\
(.045)\end{array}$ & $\begin{array}{c}.039 \\
(.049)\end{array}$ & $\begin{array}{l}(-) .032 \\
(.034)\end{array}$ & $\begin{array}{c}(-) .011 \\
(.024)\end{array}$ \\
\hline 5 & Manure \&Fertilizer in Rs. $\left(\mathrm{X}_{4}\right)$ & $\begin{array}{l}.398^{*} \\
(.139)\end{array}$ & $\begin{array}{l}(-) .004 \\
(.211)\end{array}$ & $\begin{array}{l}.206 \\
(.191)\end{array}$ & $\begin{array}{l}.320^{*} \\
(.091)\end{array}$ \\
\hline 6 & Seeds $\left(\mathrm{X}_{5}\right)$ & $\begin{array}{l}.452^{* *} \\
(.082)\end{array}$ & $\begin{array}{c}.004 \\
(.065)\end{array}$ & $\begin{array}{l}.393 * \\
(.114) \\
\end{array}$ & $\begin{array}{l}.164^{*} \\
(.043) \\
\end{array}$ \\
\hline 7 & Capital or Tractorization in Rs. $\left(\mathrm{X}_{6}\right)$ & $\begin{array}{c}.007 \\
(.015)\end{array}$ & $\begin{array}{c}.061 \\
(.036)\end{array}$ & $\begin{array}{l}.049 \\
(.033)\end{array}$ & $\begin{array}{l}.045^{*} \\
(.010)\end{array}$ \\
\hline 8 & $\mathrm{R}^{2}$ & .412 & .220 & .677 & .686 \\
\hline 9 & $\mathrm{~N}$ & 234 & 119 & 94 & 447 \\
\hline 10 & Sum of Elasticity Coefficients ( $\left.\sum \mathrm{bi}\right)$ & $0.398 *$ & 0.404 & $0.967 *$ & $0.656^{*}$ \\
\hline 11 & "t" Value for Deviation From Unity & 5.147 & 2.271 & 5.481 & 12.60 \\
\hline
\end{tabular}

Note: Figures in the Parentheses are Standard Errors

* Significant at 1 Per Cent Level

** Significant at 5 Per Cent Level

*** Significant at 10 Per Cent Level

$\mathrm{R}^{2}$ Denotes Coefficient of Multiple Determinants

N Denotes Number of Observation.

\section{Conclusion}

Per hectare cost of cultivation of wheat worked out Rs17619.21 on marginal farmers, Rs 18290.5 on small farmers, Rs. 72693.56 on medium farmers and Rs 25717.05 on overall farmers. Among the various input cost, cost B was highest among all the farm size followed by imputed value of family labour. On the other hand gross return was worked out Rs21835.45, 49504, 132175 and 50820 in respect of marginal,small,medium and overall farmers. Net returns on wheat was observed Rs.4216.24, 31213.5, 59481.44 and 25102.95 on marginal, small, medium and overall farmers.

Cost of cultivation of maize crop was incurred Rs. 15870.18 on marginal farmers, Rs 34408.09 on small farmers, Rs. 48455.35 on medium farmers Rs. 27005.45 on overall farmers. Cost B noted highest among the all types of farmers except marginal farmers, followed by imputed value of family labour. Gross return worked out Rs. 9679.24, 19143.75, 47810.34 and 18204.37 in respect of marginal, small, medium and overall farmers. Net return was Rs.-6190.94, -11264.25,-644.99 and -8801.08 in respect of marginal, small medium and overall farmers.

On paddy crop cost of cultivation was worked out Rs.17274.93, 44968.99, 107413.79 and 63266.64 in respect of marginal, small, medium amd overall farmers. Gross returns observed Rs.17516.66, 68047.61, 170032 and 93673.43 in respect of marginal, small, medium and overall farmers, and net returns were Rs.241.73, 23078.62, 62618.21 and 30406.79 in respect of marginal, small, medium and overall farmers.

On pooled crops i.e. (wheat + maize + paddy) cost of cultivation estimated Rs.15990.36, 33128.5, 67096.91and 34242.82 in respect of marginal, small, medium and overall farmers. Gross return worked out Rs.15996.58, 40530.25, 116215.95 and 43603.13 in respect of marginal, small, medium and overall farmers. Net returns Rs.6.22, 7401.75, 49119.04 and 9360.31 in respect of marginal, small, medium and overall farmers.

On wheat crop increasing returns to scale on marginal and medium farmers and constant returns to scale worked out on small and overall farmers. In the case of maize crop decreasing returns to scale on marginal small and overall farmers and constant returns to scale on medium farmers. On paddy crop constant returns to scale getting all categories of farmers. On all foodgrain crops decreasing returns to scale getting on marginal and small farmers and constant returns to scale on medium and overall farms.

\section{References}

[1] Johnston, Bruce F., J.W. Mellor,The Role of Agriculture in Economic Development ,American Economic Review, Vol. 51, No. 4, Sept. 1961, pp. 566-593.

[2] Johnston, Bruce F., P. Kilby, Agriculture and Structural Transformation: Strategies for Late Developing Countries, New York: Oxford University Press, 1975.

[3] Varian, H.R., Microeconomics Analysis, W.W. Norton Company: New York, 1992.

[4] Varian, H.R., Intermediate Microeconomics: A Modern Approach, W.W. Norton and Company: New York, 2005.

[5] Chawdhari, T.P.S., R.N. Tripathi, T.V.S. Rao, J.N. Sharma, Resource-Use and Productivity on Farms: A Comparative study of Intensive and non-Intensive Agricultural Area, Published by: National Institute of Community Development, Hydrabad, 1969, pp. 1-84.

[6] Gupta, K.K., B.R. Attari, Arun Kausal and C.S. Raghubanshi, Resource use Productivity and Allocation Efficiency on Wheat Farms of Mandi Distircst at Himachal Pradesh in 1972-73, Agriculture Situation in India, Vol. 31 No. 9, Delhi, 1976, pp. 499-501.

[7] Carter, Michael R., Identification of the Inverse Relationship between Farm Size and Productivity: An Empirical Analysis of Peasant Agricultural Production, Oxford Economic Paper 36, 1984, pp.131-145 
[8] Sharma, K., R.C. Oberoi and T.V. Moorti, An Economic Analysis of Ginger Farming in Kangra District, Himachal Pradesh, Agricultural Situation in India, vol. XLIV, No. 8, New Delhi, Nov. 1989, pp. 633-636.

[9] Thakur, D.R., K.D. Sharma and A.S. Saini, Resource use Efficiency in Agriculture Areas, Indian Journal of Agriculture Economics, Vol. 47, No. 3, July-Sept. 1992, p. 519-520.

[10] Randev, A.K., S.C. Tewari and R.K. Sharma, Rational of Resource use in Apple Cultivation-A case study of Tribal Area in Himachal Pradesh, Indian Journal of Agriculture Economic Vol. 47, No. 4, Oct-Dec. 1992, pp. 669-676.

[11] Paul, Jean Chavas, Aliber Michael, An Analysis Of Economic Efficiency In Agriculture: A Nonparametric Approach, Journal of Agricultural and Resource Economics, Western Agricultural Economic Association, Vol. 18 (01), July 1993.

[12] Ahmad, Munir, Khan Qureshi, Resent Evidence on Farm Size and Land Productivity: Implications for Public Policy, The Pakistan Development Review, 38:4 Part II, (Winter 1999), pp. 1135-1153.

[13] Tripathi, Ram Singh, Contract Farming in Potato Production: An Alternative for Managing Risk and Uncertainty, Agricultural Economics Research Review, Nov. 2005, Vol. 18, pp.47-60.
[14] Gajja, B.L., Rajendra Prasad, R.S. Mertia, Khem Chand and J.S. Sharma, Impact of Shelterbelts on Net Returns from Agricultural Production in Arid Western Rajasthan, Agricultural Economics Research Review, June 2008, vol. 21, issue 1,pp.118-122.

[15] Kamat, Dr.Manoj Subhash, Sanjay N.Tupe, Mansavi Manoj Kamat, Indian Agriculture in the New Economic Regime, 19712003:, Empirics Based on the Cobb-Douglas Production Function”, wwwhttp://papers.ssrn.com/solz/papers.cfm?Abstracted=1069501, Dec.11, 2007.

[16] Dogra, Atul, Ashok Kumar, S.K. Sharma and Vinod Kumar, An economic viability and input-output relationship in organic farming of potato in inner Himalaya, Himachal Journal of Agricultural Research 33 (2), 2007, pp. 266-269.

[17] Maity, Bipasa, Bani Chatterjee, Returns to Scale of Foodgrain Production in India: An Empirical Test, Europian Journal of Social Science, Vol.14, No.3, 2010, pp. 496-501.

[18] Bala, Brij, Nikhil Sharma and R.K. Sharma, Cost and Return Structure for the Promising Enterprise of Off-Season Vegetables in Himachal Pradesh, Agricultural Economics Research Review, vol. 24, issue 1, Jan.- June 2011, pp.141-148. 